\title{
The debate about Sraffian Supermultiplier Model and the future of heterodox growth models
}

\author{
O debate sobre o modelo supermultiplicador de \\ Sraffa e o futuro dos modelos heterodoxos de crescimento
}

\author{
JOSE LUÍS DA COSTA OREIRO* \\ GUILHERME JONAS COSTA DA SILVA*: \\ JÚLIO FERNANDO COSTA SANTOS***
}

\begin{abstract}
RESUMO: Este artigo tem como objetivo apresentar o recente debate sobre o Modelo Supermultiplicador Sraffian (SSM), que ganhou notoriedade no ambiente acadêmico após a polêmica entre Peter Skott (2016) e Marc Lavoie $(2016,2017)$ sobre a especificação da função de investimento dos novos modelos kaleckianos de crescimento e distribuição de renda. Lavoie usou o modelo SSM como uma tentativa de resgatar os modelos neokaleckianos das críticas devastadoras feitas por Peter Skott (2010) sobre a especificação da função de investimento. Nesse contexto, não apenas argumentaremos que essa operação de resgate não foi bem-sucedida, mas também questionaremos a capacidade dos modelos SSM de servir como um "fechamento alternativo" para modelos heterodoxos de crescimento e distribuição de renda, devido a três deficiências fundamentais da abordagem SSM, que são: (i) a hipótese de que o grau normal da utilização da capacidade produtiva é uma variável exógena; (ii) o investimento em expansão da capacidade é totalmente endógeno; e (iii) a aplicabilidade dessa abordagem a partir de uma estrutura de economia fechada. Também argumentaremos que os modelos kaldorianos de crescimento, que são um dos fundamentos teóricos da chamada Macroeconomia Desenvolvimentista, e modelos consistentes de fluxo de ações (SFC) parecem ser alternativas muito mais promissoras para o desenvolvimento de teorias heterodoxas de crescimento e distribuição de renda.

PALAVRAS-CHAVE: Supermultiplicador sraffiano; modelos de crescimento heterodoxos; modelos consistentes de fluxo de estoque; macroeconomia desenvolvimentista.
\end{abstract}

\footnotetext{
* Associate Professor of Economics at the Universidade de Brasília - UnB, Brasília/DF, Brasil, and Level IB Researcher at CNPq. E-mail: joreiro@unb.br. ORCID https://orcid.org/0000-0001-8955-8868.

** Associate Professor and Tutor of the Tutorial Education Program at the Universidade Federal de Uberlândia - UFU, Uberlândia/MG, Brasil. E-mail: guilhermejonas@yahoo.com.br. ORCID: https://orcid. org/0000-0002-0947-0821.

*** Adjunct Professor of Economics at the Universidade Federal de Uberlândia - UFU, Uberlância/MG, Brasil. E-mail: julio.costa@ufu.br. ORCID: https://orcid.org/0000-0002-2695-3200. Submitted: 26/March/2019; Approved: 25/April/2019.
} 
ABSTRACT: This paper aims to present the recent debate about Sraffian Supermultiplier Model (SSM), that gained notoriety in the academic environment after the controversy between Peter Skott (2016) and Marc Lavoie (2016, 2017) on the specification of the investment function of the Neo-Kaleckian models of income growth and distribution. Lavoie used the SSM model as an attempt to rescue the Neo-Kaleckians models of the devastating criticism made by Peter Skott (2010) regarding the specification of the investment function. In this context, we will not only argue that this rescue operation was not successful, but we will also question the capacity of SSM models to serve as an "alternative closure" for heterodox models of income growth and distribution, due to three fundamental shortcomings of the SSM approach, which are: (i) the hypothesis that the normal degree of utilization of the productive capacity is an exogenous variable, (ii) that investment in capacity expansion is totally endogenous; and (iii) the applicability of this approach out of a closed economy framework. We will also argue that the Kaldorian models of growth, which are one of the theoretical foundations of the so-called Developmentalist Macroeconomics, and stock-flow consistent models (SFC) seem to be much more promising alternatives for the development of heterodox theories of growth and income distribution.

KEYWORDS: Sraffian Supermultiplier; heterodox growth models; stock-flow consistent models; developmentalist macroeconomics.

JEL Classification: E12; E37; P10.

\section{INTRODUCTION}

The Sraffian Supermultiplier Model Approach (SSM) was developed initially by Serrano (1995), Bortis (1997) and Dejuan (2005), as a new adjustment mechanism between savings and investment and for the determination of the level of output and employment in the long tun.

The SSM Models in this tradition start from the following hypotheses 1 : i) there are non-capacity-generating components of autonomous demand; ii) investment expenditure is fully induced, even in the short term; iii) the investment function follows the principle of the adjustment of capital stock.

In the simplest version of this mechanism, investment is still the determinant of aggregate saving, but the adjustment variable is no longer the degree of capacity utilization, as in Neo-Kaleckian growth models, or the income distribution between profits and wages, as in neo-Keynesian growth models ${ }^{2}$; but the relationship between the non-capacity-generating autonomous expenditure and aggregate income.

The SSM model gained notoriety recently after the controversy generated by two major exponents of Heterodox Approaches, Marc Lavoie and Peter Skott, whom discusses the specification of investment function of Neo-Kaleckian models of growth and distribution.

\footnotetext{
${ }^{1}$ Fagundes (2017, p. 47).

${ }^{2}$ On these adjustment mechanisms between savings and investment, see Oreiro (2016, Chapters 3 and 5).
} 
This paper aims to present the recent debate about the SSM Model, arguing that the acceptance of SSM approach as a closure for heterodox growth models puts in danger the own future of heterodox demand-led growth models due to three significant problems of the SSM approach, namely: (i)the assumption that normal degree of utilization of the productive capacity is an exogenous variable; (ii) that investment is a completely endogenous variable; and (iii) the issue of the applicability of these models for a small open economy with government activities.

To reach this objective, in addition to this introduction, the paper is structured in five more sections. The second section presents the relationship between investment and savings in the Keynesian Approach. In the following section, the attention turns around to the controversy between Peter Skott and Marc Lavoie. In the fourth section, the robustness of the SSM approach is analyzed. In the fifth section, we will discuss the future of this approach and the heterodox theory of demand-we led growth in face of the fundamental weaknesses of the SSM approach. In the sixth section, the final remarks are presented.

\section{THE RELATIONSHIP BETWEEN INVESTMENT AND SAVINGS IN GROWTH MODELS OF KEYNESIAN INSPIRATION}

One of the major implications of the so-called Principle of Effective Demand (PED, hereafter) announced by J. M. Keynes in Chapter 3 of his General Theory of Employment, Interest, and Money (1936) is the determination of aggregate savings by aggregate investment. In the model developed by Keynes, an increase in the planned investment by firms will induce an expansion of such magnitude in the level of employment and income that, at the end of the process, aggregate savings will have increased in the same magnitude as investment (Amadeo, 1989). As a result of this argument, it follows that there cannot be a "shortage" of savings in the economic system because investment always creates a similar amount of aggregate savings.

This result is also true for an open economy, although the composition of savings between domestic savings and external savings is a variable that depends on, among other factors, the real exchange rate (Bresser-Pereira, Oreiro and Marconi, 2015). Thus, an increase in private investment will always produce an equivalent increase in total savings, but domestic savings may not keep up with the rise in the investment if the real exchange rate is overvalued. In this case, the corresponding increase of savings will be attended by "external savings", thereby increasing the external fragility of the economy in consideration ${ }^{3}$.

The extension of the PED for the long run ${ }^{4}$ was made by authors belonging to

\footnotetext{
${ }^{3}$ For more details, see Bresser-Pereira and Nakano (2003), Bresser-Pereira and Gala (2007) and BresserPereira, Oreiro and Marconi (2015).

${ }^{4}$ Long run means the time interval in which the capital stock, the qualification of the work force and the production techniques vary over time.
} 
the so-called Cambridge School of Economics (United Kingdom), which ended up being called Post-Keynesians. In this group, we can highlight Roy Harrod, Nicholas Kaldor, and Luigi Pasinetti. The models developed by these authors have as their main hypothesis that, in the long run, the normal state of a capitalist economy would be characterized by full utilization of productive capacity. In this context, the adjustment of aggregate savings to the level of investment couldn't be made through variations in the degree of capacity utilization, but by changes in income distribution between wages and profits, which became an endogenous variable to the growth.

Making the fundamental assumption that the average propensity to save of the economy as a whole is a weighted average of the propensity to save from wages and profits, each multiplied by the share of the corresponding income class in the national income; and that propensity to save out of profits is higher than propensity to save ot of wages ${ }^{5}$, it follows that profit share can be taken as an adjustment variable between investment and savings.

Consider an economy that initially operates in a long run equilibrium and that there is an increase in the investment rate. At the initial level of income distribution, the investment rate will be higher than the saving rate and the economy will be overheated. In these conditions, firms will increase profit margins, which will mean that, at aggregate level, the share of profits in national income will increase. Increasing profit share will also increase the average propensity to save in such a way that the savings rate will adjust to the new value of the investment rate. Investment continues to determine savings, but the adjustment variable is income distribution, rather than the level of employment or the degree of capacity utilization. In these models, however, a permanent increase in the rate of investment and capital accumulation is necessarily followed by an increase (reduction) of the share of profits (wages) in income. In other words, growth regime would be of the profit-led type.

More recently, many self-proclaimed "Neo-Ricardian" or "Sraffian" authors, including Serrano (1995), Bortis (1997) and Dejuan (2005), have developed a new mechanism of adjustment between savings and investment that (i) would keep the "Keynesian position" 6 of determination of savings by investment; (ii) would be

\footnotetext{
${ }^{5}$ In the case of Kaldor, because firms are compelled, in an environment of increasing returns to scale, to make investment expenditures to, at least, maintain its market share; otherwise they will lose competitiveness in the long term.

${ }^{6}$ According to Garegnani (1992, pp. 47-48): “The second answer is less homogeneous, and includes, in fact, two different positions sharing what may be called for short the Keynesian Hypothesis. This shared hypothesis is that in the long period, in which productive capacity changes, no less than in the short period analyzed by Keynes, it is an independently determined level of investment that generates the corresponding amount of savings, rather than an autonomous propensity to save that generates the level of investment as in the traditional answer. However, the savings can be generated by investment along two entirely different routes, and it is the route which is being postulated that separates the two Keynesian positions. The first route is by lowering the real wage thereby raising the normal rate of profits and, other things being equal, the proportion of profits in national income. Since the propensity to save out of profits can be safely assumed to be higher than that out of wages, the rise in the
} 
compatible with the economy operating in a long run equilibrium position in which aggregate demand and productive capacity would be fully adjusted one to the other, such that the degree of capacity utilization would be equal to the "normal" long run level, exogenously determined; (iii) would be compatible with an income distribution between wages and profits that is exogenous to the economic system; and (iv) exogenous changes in the share of wages in income would be compatible with an increase in the level of income and capital stock along the long run growth path; although it has no permanent effect over the growth rate of these variables, which would be determined by the growth rate of the non-capacity-generating autonomous expenditure. This expenditure may be the share of household consumption that is financed through increased indebtedness (Fagundes, 2016, Chapter 4), residential investment, exports, or government spending. In the simplest version of this mechanism, consumption financed by indebtedness is chosen as the engine of growth of autonomous demand. This adjustment mechanism became known as the SSM Model.

How does this mechanism work? The basic idea is straightforward. The starting point of the SSM is to observe that the average propensity to save may be different from the marginal propensity to save if we consider the existence of an autonomous term in the saving function. Following Freitas and Serrano (2015), suppose a saving function written as:

$$
S=s . Y-Z
$$

where $Y$ is aggregate output and $Z$ is autonomous consumption.

If we divide $S$ by $Y$, we get:

$$
\frac{S}{Y}=s-z
$$

where $z=\frac{Z}{Y}$.

Now, consider that:

$$
\frac{1}{Y}=h
$$

where $b$ is the share of investments in aggregate output.

The authors assume that the share of investment in aggregate output is constant in the short run. The equilibrium in the goods market for a closed economy and without government activities requires that $\left(\frac{I}{y}=\frac{s}{\gamma}\right)$ :

$$
h=s-z
$$

where $h$ and $s$ are exogenous variables.

\footnotetext{
proportion of savings to consumption will follow. The second route through which investment can generate the corresponding amount of savings is by raising the level of output together with the corresponding productive capacity, with-out any need to change the real wage and the normal rate of profits. For brevity we shall refer here to the theoretical positions characterized by those two routes as, respectively, the 'First' and the 'Second' Keynesian Positions".
} 
Thus, it follows that the adjustment variable must be $z$, that is, the autonomous consumption per unit of aggregate output. For example, an exogenous increase in the investment rate will lead to a reduction of $z$ so that the aggregate saving rate adjusts to the new investment rate. The investment will continue to determine savings, but the adjustment variable will no longer be the degree of capacity utilization or the functional income distribution, but the relationship between autonomous consumption and the aggregate output.

However, in the medium and long run, the propensity to invest is no longer a constant. It must adjust over time depending on the difference between the effective and the normal degree of utilization of the productive capacity, such that:

$$
\frac{d h}{d t}=h \cdot\left(u-u_{n}\right)
$$

where $u$ is the degree of capacity utilization and $u_{n}$ is the normal degree of capacity utilization.

Moreover, the relation between the autonomous consumption and the capital stock $z$ must change over time based on the following equation:

$$
\frac{d z}{d t}=z \cdot\left(g_{z}-g_{k}\right)
$$

where $g_{z}$ is the growth rate of autonomous consumption, which is considered an exogenous variable in the model; and $g_{k}$ is the growth rate of the capital stock.

Finally, the degree of utilization of the productive capacity will adjust over time-based on the equation:

$$
\frac{d u}{d t}=u \cdot\left(g-g_{k}\right)
$$

where $g$ is the growth rate of the aggregate output.

The long run equilibrium of the system is such that:

$$
\frac{d h}{d t}=\frac{d z}{d t}=\frac{d u}{d t}=0
$$

In steady-state we will have $u=u_{n} ; g_{z}=g_{k}$; and $g=g_{k}$; that is, the degree of capacity utilization will be equal to normal, but the growth rate of the aggregate output and the capital stock will be equal to the rate of growth of the autonomous consumption.

In the SSM model, the capacity utilization is determined by the supply conditions of the economy in the long run, but the growth rate of the output and the capital stock is determined by the growth rate of the autonomous demand component that does not create capacity (non-capacity-generating autonomous demand). It is a model in which Say's Law applies to the level of capacity utilization, but the PED is valid for the growth rate of the output and capital stock.

In this way, an increase in the growth rate of autonomous consumption will accelerate the growth rate of aggregate demand relative to the growth rate of the capital stock $\left(g_{k}\right)$, resulting in an increasing level of capacity utilization $(u)$, which 
will become higher than the normal level of capacity utilization $\left(u_{n}\right)$. As this happens private sector, pressured by competition, will accelerate its investment plans, thereby increasing the investment rate $(b)$, which will accelerate the growth rate of the capital stock $\left(g_{k}\right)$ and therefore reduce the level of capacity utilization. The increase in $h$, in turn, will reduce the value of $z$, so that throughout the process of transition to the new long run equilibrium the level of output and capital stock should grow faster than autonomous consumption. At the end of the process, there will have been a permanent increase in the growth rate of output and capital stock and an equally permanent increase in the level of output and capital stock, but the degree of utilization of the productive capacity will have returned to its normal value.

In recent years, this SSM model has gained popularity in Brazilian and international academic circles due to the controversy between Lavoie $(2016,2017)$ and Skott (2016) regarding the specification of the investment function of the NeoKaleckian models of growth and distribution, which began in Skott's seminal paper published in 2010. The analysis of this controversy and its relationship with SSM will be presented in the next section.

\section{THE CONTROVERSY BETWEEN PETER SKOTT AND MARC LAVOIE AND THE SRAFFIAN SUPERMULTIPLIER}

To understand the recent controversy between Skott and Lavoie regarding the specification of the investment function in the Neo-Kaleckian models of growth and distribution, a brief introduction is required.

These models were developed from Rowthorn's (1981) seminal paper as an alternative to the Cambridge school's models of growth and distribution in which the functional income distribution was the adjustment variable between savings and investment and the economy operated with full utilization of productive capacity $\left(u=u_{n}\right)$ along a balanced growth path ${ }^{7}$.

In the Neo-Kaleckian models of growth and distribution, the profit share in income is determined at the microeconomic level, based price decisions taken by firms that operates in non-competitive markets. A monopolistic competition environment is assumed where firms can set a price above marginal cost, but in which the level of atomization in the market is still large enough to prevent firms from being forced to take into account, in its pricing strategy, the reaction of its competitors.

In this context, the price formation by the firms is based on a fixed mark-up rate over unit production costs, a rate that reflects what Kalecki (1954) called "monopoly power" that is, the capacity to fix a price above the unit production costs. The degree of monopoly reflects variables related to the market structure in which firms operate, such as the degree of concentration of sales, the barriers to

\footnotetext{
${ }^{7}$ For more details, see Oreiro (2018).
} 
entry of new competitors and the existence of substitutes to the goods produced by the firms. Since such variables reflects the structure of the market; they therefore change slowly over time; than we can consider the "degree of monopoly" and, thus, the mark-up rate, as exogenous variables.

Following Kalecki (1954, p.35), we can demonstrate that the profit share, which we will call $\pi$, is given by:

$$
\pi=\frac{m}{1-n}
$$

where $m$ and $n$ are positive and reflect the degree of monopoly; $\pi=\frac{m}{1-n}$ is the mark-up rate $(n<1)$. The Neo-Kaleckian growth models, such as the Cambridge school models, assume the differentiation between the propensities to save on the basis of the income class (profits and wages), as well as the hypothesis that the propensity to save out of profits $\left(s_{2}\right)$ is greater than the propensity to save out of wages $\left(s_{1}\right)$. Contrary to the SSM Approach, however, there is no autonomous term in the saving function, so that the aggregate saving can be written as:

$$
S=s_{1} \cdot w \cdot Y+s_{2} \cdot(1-w) Y
$$

Without loss of generality, we can assume that $s_{1}=0$, that is, "workers spend what they get," such that the saving function reduces to the following expression:

$$
s_{k}=s_{2} \cdot(1-w) \cdot u \cdot a
$$

We will now define the variable:

$$
s_{k}=\frac{s}{K}
$$

where $s_{k}$ is aggregate savings per unit of capital. Thus, we get:

$$
s_{k}=s_{2} \cdot(1-w) \cdot u \cdot a
$$

where $u=\frac{\gamma}{Y_{p}}$ is the level of utilization of productive capacity; $Y_{p}$ is the potential output; $Y$ is the effective output; $a=\frac{\gamma_{p}}{K}$ is capital productivity.

Now we need to specify the investment function. The Neo-Kaleckian canonical model $^{8}$ assumes that the desired growth rate of capital stock $\left(g_{k}\right)$ is given by:

$$
g_{k}=b+c \cdot\left(u-u_{n}\right)
$$

where $b$ is the autonomous component of the growth rate of capital stock, which reflects the animal spirits of entrepreneurs, that is their disposition to invest regardless the current economic activity; and $c$ is the marginal propensity to invest.

\footnotetext{
${ }^{8}$ The term canonical is for differentiate from the Neo-Kaleckian models, arising from the seminal paper of Bhaduri and Marglin (1990).
} 
The term $c .\left(u-u_{n}\right)$ reflects the mechanism of investment accelerator, i.e., the idea that firms seek to adjust the size of productive capacity to expected growth of sales. Thus, when the degree of utilization of the productive capacity is higher than normal, it follows that firms will accelerate its investment plans to restore the "desired" or "normal" level of idleness of productive capacity.

The macroeconomic equilibrium for a closed economy and without government requires that equations (13) e (14) be the same:

$$
s_{k}=g_{k}
$$

In other words, it requires that:

$$
b+c \cdot\left(u-u_{n}\right)=s_{2} \cdot(1-w) \cdot u \cdot a
$$

Since income distribution is exogenously determined, it follows that the adjustment variable between saving and investment will have to be the degree of utilization of the productive capacity. Solving the above expression for $u$, we get that the degree of utilization of the productive capacity of equilibrium will be given by'

$$
u^{*}=\frac{\left(b-c u_{n}\right)}{s_{2}(1-w) a-c}
$$

We can observe that except by a "happy coincidence," the degree of utilization of the productive capacity will be different from the normal degree of capacity utilization. In order for the equilibrium to be stable is necessary to assume that:

$$
s_{2} \cdot(1-w) \cdot a-c>0
$$

In other words, the marginal propensity to save given by $s_{2}(1-w)$ should be higher than the marginal propensity to invest given by $c$.

An important result of this model is that:

$$
\frac{\partial u}{\partial(1-w)}<0
$$

An increase of the profit share in income reduces the degree of capacity utilization defining a wage-led demand regime. From equation (14), we know that:

$$
\frac{\partial g}{\partial u}=c>0
$$

So we get:

$$
\frac{\partial g}{\partial(1-w)}=\left(\frac{\partial g}{\partial u}\right)\left(\frac{\partial u}{\partial(1-w)}\right)<0
$$

Thus, an increase in the profit share in income is associated with a reduction in the rate of capital accumulation; that is, growth regime is also wage-led ${ }^{10}$. Another interesting result of this model is that an increase in the propensity to save out of

\footnotetext{
${ }^{9}$ Oreiro (2016, p. 114).

${ }^{10}$ Skott (2012, p. 3).
} 
profits will result in a reduction in the degree of capacity utilization and in the rate of capital accumulation, which is known as the "paradox of thrift" or "paradox of saving." This paradox, pioneered presented by Keynes (1936) in his General Theory, says that the attempt of the community as a whole to increase its own savings by means of increasing the saving share of income will result in a contraction of such magnitude in aggregate output and employment that, at the end of the process, community will be saving exactly the same as before, because aggregate income will have dropped in the magnitude given by the increase of its propensity to save.

Peter Skott's criticism of the Neo-Kaleckian models of growth and distribution starts from this issue. Skott $(2010,2012)$ argues that the degree of capacity utilization in the standard Neo-Kaleckian model is hypersensitive to changes in the propensity to save out of profits. According to Skott $(2012$, p. 3):

Using this alternative specification of the investment function, they showed that the Keynesian stability condition need not produce stagnationist and wage-led regimes. The utilization rate remains an accommodating variable, however, and the main difference between the investment functions is that the sensitivity of investment to changes in utilization has been reduced, relative to the sensitivity concerning the profit share.

To understand this issue, it is necessary to calibrate the model that we presented previously. Consider that: $c=0,01 ; w=0,6 ; a=0,5 ; b=0,0 ; s_{2}=0,11$ e $u_{n}=0,85$. In these conditions, an $81.8 \%$ increase in propensity to save (from 0.11 to 0.2 ) leads to a $60 \%$ decrease in the capacity utilization and a $27.2 \%$ fall in the rate of capital accumulation, so the degree of capacity utilization is 2.2 times more sensitive to a shock on the propensity to save than the rate of capital accumulation ${ }^{11}$.

This problem of hypersensitivity of the degree of capacity utilization to shocks over the propensity to save arises from the specification of the investment function. According to Skott (2012, p. 4), the main problem of the investment function in the Neo-Kaleckian growth models is that the investment response to changes in the degree of capacity utilization is low and constant over time ${ }^{12}$. In particular, the short run sensitivity of the rate of capital accumulation to changes in the degree of capacity utilization is considered to be equal to the long run sensitivity of that variable. In the short run, it is reasonable to assume that the investment is relatively unresponsive to the degree of capacity utilization and, besides that, low sensitivity is also a necessary condition for the stability of the short run equilibrium in the NeoKaleckian models ${ }^{13}$. But this is an unacceptable hypothesis for the long run since

\footnotetext{
11 Oreiro (2016, p. 116).

${ }^{12}$ For More details, see Skott (2012).

${ }^{13}$ More specifically, for the short run equilibrium to be stable it is necessary that the sensitivity of the desired savings to changes of the degree of capacity utilization to be higher than the sensitivity of the investment to variations in this variable.
} 
changes in aggregate demand generally have lagged effects over investment, which will act to increase the long run sensitivity of capital accumulation to the level capacity utilization.

According to Skott (2012, p. 5):

The insensitivity of investment is plausible in the short run, but changes in aggregate demand have lagged effects on investment, and a weak impact effect does not guarantee that the long-term effects of a sustained increase in aggregate demand and utilization will be weak as well.

The solution proposed by Skott $(2012$, p. 6) is to assume a Harrodian pattern of capital accumulation in which:

$$
\frac{d g_{k}}{d t}=v \cdot\left(u-u_{n}\right)
$$

where $v$ is a parameter that represents the sensitivity of the variation of the growth rate of the capital stock to the divergences between the effective and normal degree of utilization of the productive capacity.

In these conditions, in steady-state, we will have to $u=u_{n}$, but the level of the growth rate of the capital stock and the level of the growth rate of the output will be indeterminate ${ }^{14}$. In this context, Skott proposes the adoption of the "growth function":

$$
g=g[e,(1-w)]
$$

where $e$ is the employment rate, and $(1-w)$ is the profit share in income ${ }^{15}$.

The growth function is such that $\frac{d g}{d(1-w)}>0$, in such a way that growth regime is profit-led, instead of wage-led, as in the canonical Neo-Kaleckian model.

The defense of the Neo-Kaleckian models was presented by Lavoie (2016, 2017), probably inspired by the paper of Freitas and Serrano (2015). To deal with the problem of specifying the investment function, Lavoie bought the idea of the Neo-Ricardians that investment in expansion of capacity utilization is full endogenous $^{16}$. Thus, the term $b$ may be constant in the short run, but in the long run, it should be adjusted based on the following equation:

$$
\frac{d b}{d t}=b \cdot\left(g-g_{k}\right)
$$

\footnotetext{
${ }^{14}$ Given Capital Productivity.

15 The microeconomic grounds are made in his book Conflict and Effective Demand in Economic Growth, published in 1989.

${ }^{16}$ Fagundes (2017) presents in Chapter 3 of his doctoral thesis a model of the supermultiplier, in which the investment is partially autonomous and analyzes its' stability conditions. Stability analysis shows, however, that if growth is led by investment then the stability condition of the model will be difficult to be satisfied. (p. 134).
} 
So, when output growth rate is higher than the capital stock growth rate, the autonomous component of the capital stock growth rate should accelerate, which in practice, means an increase in the propensity to invest. The problem with this mechanism is that it leaves the rate of output growth indeterminate. This is the moment when SSM enters in the story.

Lavoie (2016) assumes that the consumption of capitalists has an autonomous component that increases the rate $g_{z}$. Thus, in the long run equilibrium, the output and capital stock growth will be determined by the growth of the non-capacitygenerating autonomous demand (growth of autonomous capitalist consumption); and, in addition, the degree of utilization of the productive capacity will converge to the normal level in the long term, thus addressing the criticisms made by Marxist authors such as Duménil and Levy $(1995,1999)$ for whom Neo-Kaleckian models were not applicable to the long run dynamics of capitalist economies precisely because of the non-convergence of the degree of utilization of the productive capacity to its normal value in the long-run.

The rescue operation of the Neo-Kaleckian models of growth and distribution by Lavoie involved the integration of various aspects of the SSM approach. First, Lavoie accepted the full endogenization of investment in the expansion of production capacity, eliminating any autonomous component of the investment function. According to Lavoie (2016, pp. 172-173):

In its more straightforward version, an autonomous component of consumption by capitalists is added to the canonical investment function of the Kaleckian model, with this autonomous component being assumed to grow at an exogenously given rate. In this first version, the actual rate of capacity utilization is not generally equal to its normal or desired value, unless the rate of growth of autonomous capitalist consumption happens to be equal to the constant term in the investment function. (2016, pp 172-173)

The problem with this choice is that he kicked up an extremely important theoretical element for Keynesian economists that is the role of animal spirits as an element of instability in the economic system. This point was raised in the paper by Dávila-Fernandes, Oreiro, and Punzo (2017) for whon Lavoie was abandoning the spirit of the "Keynesian message" with his solution.

The second problem is that the engine of autonomous demand growth ceased to be the investment in capacity expansion and became the growth of capitalists' consumption. According to Lavoie (2016, p. 173):

The long run equilibrium growth rate in the model is still determined by the exogenously given rate of growth of autonomous capitalist consumption, but it turns out that under reasonably weak conditions the actual 
rate of capacity utilization will converge towards the normal or desired rate of capacity utilization.

Besides being an inversion of the causa causans of economic activity proposed by Keynes in the General Theory; if capitalist consumption is the engine of long run growth, then the higher is the concentration of wealth (not necessarily income) on the hands of capitalists higher will be the expected long run growth, since higher should be the rate of growth of capitalists' consumption. This result seems to be incompatible with the progressive position advocated by Lavoie and the other Neo-Kaleckian economists.

What remained of the original Neo-Kaleckian approach was the exogenous nature of income distribution, which is determined at microeconomic level by the pricing decisions taken by the firms. But this was only possible because the SSM approach also requires that functional income distribution to be exogenous to the growth process. What differentiates the Neo-Kaleckian approach from the SSM approach is just the explanation of the income distribution between wages and profits. For Neo-Kaleckians income distribution is determined at the microeconomic level, for neo-Ricardians it is determined by social conventions and by the state of class struggle.

The result of wage-led demand and growth regimes was maintained only for the level of output and capital stock, but not for the degree of capacity utilization and for the rate of growth of capital stock. According to Lavoie (2016, pp. 172-173):

The model produced implies wage-led growth, not in the sense of raising the long run equilibrium growth rate of the economy when the wage share rises (and the profit share falls), since the rate of growth of the economy in the medium or long run is determined by the exogenous growth rate of the autonomous part of capitalist consumption, but in the sense of raising the average rate of growth during the traverse after the wage share increases - something that many have argued to be a suitable way of examining growth effects, that is, focusing on averages rather than steady-state values.

This is probably the reason why leading Neo-Kaleckians such as Marc Lavoie and Amitava Dutt "have fallen in love" with the SSM approach, which had been largely neglected by the literature on heterodox models of income growth and distribution for approximately two decades. The approval of heterodox economists such as Lavoie and Dutt to SSM approach has helped to remove the Brazilian NeoRicardian school from the academic ostracism, which has always been viewed with disdain by the mainstream of heterodox economics in Brazil composed by PostKeynesians and Neo-Schumpeterians, due to the decisive intellectual influence of Fernando Carvalho in the Post-Keynesian school, and Mário Possas at the NeoSchumpeterian school. 


\section{CRITICISMS OF THE SRAFFIAN SUPERMULTIPLIER, THE THIRWALL MODEL AND THE DEVELOPMENTAL MACROECONOMICS}

Regardless of the theoretical and political economy problems that the incorporation of the SSM into the formal structure of the Neo-Kaleckian models of growth and income distribution can cause remains a fundamental theoretical question that consists of evaluating the robustness of the SSM approach. In other words, are SSM models robust in the sense that they present results that do not depend on restrictive assumptions about the functioning of the economic system? The answer to that question is definitely no.

The robustness of the SSM approach was criticized in a recent paper by Nikiforos (2018). According to Nikiforos, the SSM approach has two main problems. First, it considers the normal degree of capacity utilization as an exogenous variable and independent of aggregate demand. The problem with this hypothesis is that the role of demand in determining the level of productive capacity utilization disappears and the model becomes similar to the "classic model" in the long run. However, the idea that the normal degree of capacity utilization is a technological factor or determined by the conventions prevailing among entrepreneurs is incorrect. Indeed, it can be shown that if the economy operates with increasing returns to scale, then the normal degree of capacity utilization becomes an endogenous variable so that an increase in aggregate demand will result in an increase in the normal or desired level of capacity utilization.

In this context, Oreiro (2004) showed that the incorporation of a normal endogenous level of capacity utilization into the structure of the Neo-Kaleckian growth models allows:

I. unplanned excess capacity to converge to zero in the long run, thereby circumventing the criticisms made by Marxist authors such as Duménil and Lévy $(1995,1999)$ to Neo-Kaleckian models; and

II. the growth rate of output and capacity utilization will be entirely determined by the autonomous component of the investment function, thus giving a key role to capitalists' animal spirits in long run growth.

Another criticism of Nikiforos to the SSM is that it disregards the implications in terms of the relationships between flows and stocks of autonomous spending financed through debt. Let's consider that the autonomous consumption of households is financed by bank credit as in the model developed by Freitas and Serrano (2015).

Financing by bank credit generates an intrinsic dynamic for the stock of debt of households with commercial banks and, therefore, for the level of household indebtedness, that is, the debt-to-income ratio. While household indebtedness should stabilize at some level in the long run, increasing households' financial fragility during the transition to long run equilibrium may increase the perceived risk of commercial banks, leading them to raise interest rates on bank loans and 
eventually to practice credit rationing ${ }^{17}$. The increase in the cost of credit associated with reduced credit availability due to credit rationing may lead households to reduce the growth rate of their spending. But in this case, autonomous consumption will have ceased to be autonomous.

Similar reasoning can be applied to government spending. According to Nikiforos (2018, p.12), government spending is not an autonomous component, but it is not either directly dependent on GDP. The only component of the autonomous demand for which this reasoning does not apply is for exports, and even so, only in the case of small open economies.

Another critical line of the SSM approach was developed recently by Oreiro and Costa Santos (2019). These authors elaborate an SSM model for a small open economy with government activities. However, rather than considering the existence of a single growth driver for autonomous demand that does not create capacity as Freitas and Serrano (2015), the authors consider an economy in which exports and government spending grow at an exogenous rate, though not necessarily equal to each other. The authors assume other assumptions such as: (a) the real exchange rate is fixed at the level of purchasing power parity; (b) the marginal propensity to import is constant, and the distribution of income between wages and profits is exogenous; (c) capital mobility is zero so that deficits in the trade balance can only be financed through the reduction of international reserves, up to the point where they reach zero.

The authors then examine the long run equilibrium properties and the local stability conditions in three different scenarios. In scenario 1 , the growth rate of exports equals the growth rate of government spending. In scenario 2 , the growth rate of exports is higher than the growth rate of government spending. Finally, in scenario 3, the growth rate of exports is lower than the growth rate of government spending.

The results obtained by the authors show that:

- In scenario 1 , the economy converges to a long run equilibrium in which the international reserves/GDP ratio and the public debt/GDP ratio are both constant and positive. It is a scenario that can be considered as economically feasible;

- In scenario 2, the economy converges to a long run equilibrium in which the reserves / GDP ratio is constant and positive, but the ratio of public debt to GDP is negative. It is a scenario in which the external solvency condition of the economy is respected, but in which the government becomes

\footnotetext{
${ }^{17}$ Fagundes (2017) in Chapter 4 of his doctoral thesis develops a supermultiplier model in which the autonomous consumption of workers is financed with bank credit. Although the model is compatible with the financial position taxonomies developed by Minsky (1986), the author does not elaborate any implication of the relationship between the evolution of workers' indebtedness and the financial fragility perceived by commercial banks. Thus, the interest rate on bank loans is kept constant over time, regardless of the level of debt of the workers.
} 
a net creditor of the private sector. Although a situation in which government is a creditor, rather than a debtor, of the private sector seems extremely improbable, it does not represent an economically impossible situation, so scenario 2 cannot be dismissed in purely analytical terms; and

- Finally, in scenario 3, the economy converges to a long run equilibrium position in which the public debt/GDP ratio is constant and positive, but the international reserves/GDP ratio is negative. The problem is that if the economy in question does not issue the international reserve currency, then, in scenario 3, the economy converges to an economically impossible position to sustain, i.e., it cannot be a long run equilibrium.

The results of the model developed by Oreiro and Costa Santos (2019) show that the SSM model only applies to the case where the growth engine of autonomous demand that does not create capacity is exports. A similar result was also found by Nah and Lavoie (2017). But in this case, the SSM model becomes indistinguishable from the balance-of-payments growth model developed by Thirwall (1979). The idea that the long run growth of small open economies that do not have a reserve or convertible currency can only be led by exports is one of the central aspects of the Brazilian New Developmental school, whose theoretical foundations are exposed in Bresser-Pereira, Oreiro and Marconi (2015).

\section{WHAT AFTER THE SUPER MULTIPLIER? WHAT IS THE FUTURE OF GROWTH THEORY DRIVEN BY AGGREGATE DEMAND?}

The closure given by SSM to the heterodox models of growth and distribution has two fundamental deficiencies. The first, emphasized by Nikiforos (2018), is the hypothesis that the normal degree of capacity utilization is exogenous which - in addition to making the level of capacity utilization determined by long run supply conditions, thus making it similar to the "classic model" - is imply ignores all the literature developed in the last 30 years, in which the degree of capacity utilization is endogenized (Skott, 1989; Oreiro, 2004; Nikiforos, 2013). In addition, the endogenization of the degree of utilization of productive capacity allows the undesired excess capacity in the Neo-Kaleckian models to converge to zero in the long run; thus responding to the criticism of the Marxist authors (Duménil and Lévy; 1995, 1999) about the capacity of the Neo-Kaleckian models to represent the long run properties of capitalist economies.

The second criticism - elaborated by Oreiro and Costa Santos (2019) and inspired by Bortis (1997), one of the founding fathers of the SSM approach - refers to the applicability of the SSM approach to a small open economy with governmental activities. The usual models of the Sraffian Supermultiplier - such as that elaborated by Freitas and Serrano (2015) and Lavoie $(2016,2017)$ - assume a closed economy without governmental activities so that the source of autonomous demand growth that does not create capacity is the consumption of households, 
and can be financed by credit, as in Freitas and Serrano (2015), or by the wealth of the capitalists, as in Lavoie $(2016,2017)$.

In this type of framework, there is no space, by definition, to deal with issues related to the balance of payments constraint and/or the intertemporal solvency of public sector. However, when designing an SSM model for a small open economy with government activities, and where the growth rate of exports and government spending grows at an exogenous but not necessarily equal rate, Oreiro and Costa Santos (2019) showed that the existence of a balanced long run growth trajectory is only possible in the case where the export growth rate is equal to or higher than the rate of growth of government spending, from which it can be concluded that the SSM approach can be only applied to the case of an export-led growth regime.

In this case, however, the SSM approach becomes indistinguishable from Thirwall's $(1979,2002)$ growth model with a balance of payments constraint, but also compatible with the developmentalist macroeconomics, which states that the long run growth of economies which establishes that the long run growth of capitalist economies that do not have convertible currency, that is, middle-income countries, should be led by exports of manufactured goods (Bresser-Pereira, Oreiro, and Marconi, 2015).

Because of these shortcomings, it does not seem likely that the SSM approach will survive for long time, once the initial euphoria of being perceived as a life jacket for the Neo-Kaleckian growth and income distribution has passed.

If this conjecture is correct, then what is the future of demand-led growth models? Were they condemned to disappear? We do not believe that is the case.

Let's start with the Neo-Kaleckian models. According to Peter Skott (2010), the specification of their investment function was strong, but it can be answered through the endogenization of the normal degree of capacity utilization. By making " $u$ " a constant in the short run, but an endogenous variable in the long run, then the marginal propensity to invest in the long run can be higher than the marginal propensity to invest in the short-run, thus addressing Skott's criticism.

This endogenization will, however, lead to the emergence of multiple equilibria for the degree of capacity utilization and the profit share, as showed in Oreiro (2016, pp. 122-123). In particular, we will have two long run equilibria, the first equilibrium with high level of capacity utilization and low-profit share in national income; and another equilibrium with a low level of capacity utilization and a high profit share in income. The engine of long run growth will, however, be the autonomous component of investment demand, determined by the animal spirits of the capitalists. In this context, the distinction between wage-led and profit-led growth regimes loses all sense, since changes in the income distribution between wages and profits will have no impact on autonomous investment.

Another approach to demand-led growth consists of Kaldorian growth models, of which the Thirwall model is a particular case. The essential aspect of the Kaldorian growth models is to combine Harrod's dynamic foreign trade multiplier with a dynamic equation for the growth rate of exports, an equation for the dynamics of the 
rate of inflation, and an equation for the growth rate of labor productivity, inspired by the so-called "Kaldor-Verdoorn law" (Oreiro, 2016, Chapter 4, pp. 79-85).

The canonical Kaldorian model, pioneered by Dixon and Thirwall (1975), is not only compatible with a steady-state solution; as it still shows under what conditions a particular economy can catch-up to the rest of the world, as well as under what conditions a falling-behind situation can occur. The Kaldorian canonical model was recently extended by Santana and Oreiro (2018) in order to incorporate imperfect capital mobility, monetary policy conducted by means of a Taylor rule in a inflation targeting regime and a floating exchange rate regime.

In this framework, Santana and Oreiro show that monetary policy can affect the long run growth rate of the real income, through a permanent increase in the inflation target, by inducing a temporary undervaluation of the real exchange rate, which remains, for some periods, above the level of industrial equilibrium, thus stimulating an increase in the share of manufacturing industry in GDP. As the share of manufacturing industry has a positive impact over the Kaldor-Verdoorn coefficient of induction of labor productivity growth by the growth of output; it follows that the natural growth rate of the economy will increase as a direct result of these developments. It follows, therefore, that the Kaldorian growth models not only have a more comprehensive theoretical framework than the SSM approach but appears to be much more promising in terms of possibilities for future developments.

Another possibility of development for demand-led growth models is to abandon the equilibrium or steady-state approach and enters in the realm of dynamic analysis, in which the objective is not to describe the properties of an economic system in a steady position, but the dynamics of the system over time. A recent example of this type of approach is the paper of Dávila-Fernandez and Sordi (2017).

In this paper, Dávila-Fernandez and Sordi expand Goodwin's (1967) distributive cycle model for an open economy in order to incorporate a balance of payments constraint. Moreover, the authors incorporate a function of technical progress, in which the rate of growth of labor productivity is a function of the level of utilization of productive capacity, and an investment function in which the growth rate of the capital stock is a positive function of the level of capacity utilization and negative for the wage-share in income, as in the model of Bhaduri and Marglin (1990). The result is a model with four differential equations in which there are regular fluctuations in the growth rate of output and capital stock, the degree of capacity utilization, the wage share (and profit share) in income.

Besides that, we cannot forget the stock-flow consistent (SFC), which have gained increasing importance in heterodox literature from the book of Godley and Lavoie (2007). These models allow integration between the two strands of PostKeynesian thought (Oreiro et al., 2018), and can be easily adapted to be converted into growth models, as it is adequately demonstrated in Chapter 11 of Godley and Lavoie $(2007)^{18}$, where the authors present a prototype of SFC growth model. This

${ }^{18}$ Brochier and Macedo Silva (2018) attempted to incorporate the SSM model into a theoretical SFC 
model allows the analysis of the interaction between the real and financial variables of a capitalist economy, an element absent from the SSM approach. It should also be noted that in the prototype of growth model developed by Godley and Lavoie, the level of production is determined by the demand expected by firms so that the model is fully compatible with the Principle of Effective Demand.

In short, there is a wide range of possibilities for theoretical research in the field of growth and income distribution models besides the SSM approach, which does not seem to us to be a very fertile field for new developments.

\section{CONCLUDING REMARKS}

This paper aims to analyze the controversy of Peter Skott and Marc Lavoie, as well as the relation of the controversy with the Sraffian Supermultiplier (SSM).

The Sraffian Supermultiplier Model (SSM) can be understood as a third mechanism of adjustment between saving and investment, in which the aggregate saving always adjusts to the aggregate investment. This adjustment mechanism not only allows to consider the functional income distribution as an exogenous variable to the process of economic growth, as well as it is compatible with the long run equilibrium of the system, by ensuring the convergence of the effective degree of capacity utilization to the long run normal level.

The SSM model was recently used by Marc Lavoie to rescue the Neo-Kaleckian models of growth and income distribution from Peter Skott's devastating criticism (2010) regarding the specification of investment function of these models. Peter Skott (2010) stated that the major problem of the investment function in the Neo-Kaleckian growth models is that the investment response to changes in the degree of utilization of productive capacity is low and constant over time.

The problem is that the rescue operation of the Neo-Kaleckian models came with a non-negligible theoretical cost. Firstly, the full endogenization of the investment in capacity expansion needed to incorporate the SSM into the formal structure of the Neo-Kaleckian models eliminated the channel by which changes in the animal spirits of the entrepreneurs could affect the degree of utilization of produc-

framework, in which it was possible to analyze the interactions between flows and stocks over time, as well as the influence of financial variables over output growth and capital accumulation. However, as emphasized by the authors themselves, this incorporation is only possible through the endogenization of the autonomous component of consumption expenditures; which is determined by the rentier wealth stock, and is thus influenced by the evolution of savings - and consequently the level of income - over time. Thus, the essential aspect of the SSM approach - the existence of an autonomous component of demand that does not create productive capacity - is simply lost, since the exogenous component of demand ceases to be endogenous. Also, we must emphasize that the formalization of the "autonomous component" of consumption by Brochier and Macedo Silva (2018) is similar to what is widely done in the SFC literature. Finally, the results obtained in terms of the validity of the "paradox of costs" and the "paradox of thrift" are not new in the SFC literature, so that (sic) incorporation of the Sraffian Supermultiplier into the literature of the SFC models does not add any new theoretical result. 
tive capacity and the growth rate of the capital stock in the equilibrium configuration of the model. If Lavoie's goal $(2016,2017)$ with this solution was to preserve the "Keynesian message"; then his attempt was unsuccessful; since the essential aspect of Keynes's General Theory (1936), as described by the Keynes himself in the preface to his magnum opus, is precisely to show that a monetary production economy "is essentially an economy in which changes in the vision of the future can influence the amount of employment and not just their direction". The complete endogenization of the investment eliminates one of the essential elements of the "Keynesian message".

Last, but not least, the incorporation of the SSM into the structure of the NeoKaleckian models implies a shift of the engine of long run growth from capital accumulation to capitalist consumption. This change opens the way for the defense of trickle-down economics, since the growth rate of capitalist consumption is related to the stock of wealth possessed by them, from which we can infer that policies that privilege the top $1 \%$, by stimulating long run growth, will benefit workers, for example by enabling faster job creation. This result seems not to have been perceived by Lavoie and Neo-Kaleckians since these authors belong indisputably to the progressive field of economic thought.

Finally, we argue that the Kaldorian models of growth, the basis of the socalled developmentalist macroeconomics; and stock-flow consistent (SFC) models appear to be much more promising alternatives for the development of heterodox theories of growth and income distribution than the Sraffian Supermultiplier approach.

\section{REFERENCES}

AMADEO, E.J. (1989). Keynes's Principle of Effective Demand. Edward Algar: Aldershot.

BHADURI, A., MARGLIN, S. (1990). "Unemployment and the real wage: The economic basis for contesting political ideologies". Cambridge Journal of Economics 14(4), 375-393.

BORTIS, H. (1997). Institutions, Behavior and Economic Theory: a contribution to Classical-Keynesian Political Economy. Cambridge University Press: Cambridge.

BRESSER-PEREIRA, L. C; OREIRO, J. L; MARCONI, N. (2015). Developmental Macroeconomics: New Developmentalism as a growth strategy". Routledge: Londres.

BRESSER-PEREIRA, L. C.; NAKANO, Y. (2003) Crescimento Econômico com Poupança Externa? Revista de Economia Política, vol. 23, nº 2 (90).

BRESSER-PEREIRA, L.C.; GALA, P. (2007). Por que a poupança externa não promove crescimento. Brazilian Journal of Political Economy, 27(1), 3-19.

BROCHIER, L; MACEDO SILVA, A.C. (2018). "The supermultiplier stock-flow consistent model: the "return" of the paradoxes of thrift and costs in the long run?". Cambridge Journal of Economics. doi:10.1093/cje/bey008.

DÁVILA-FERNANDES, M.; OREIRO, J.L; PUNZO, L. (2017). "Inconsistency and over-determination in Neo-Kaleckian growth models: a note". Metroeconomica.

DÁVILA-FERNÁNDEZ; M. J; SORDI, S. (2017). "Distributive cycles and endogenous technical change in a BoPC growth model”. Quaderni Del Dipartimento Di Economia Politica E Statistica, N. 760 , outubro. 
DEJUÁN, O. (2005). "Paths of accumulation and growth: towards a Keynesian long-period theory of output." Review of Political Economy 17(2): 231-52.

DIXON, R.J. AND THIRLWALL, A.P. (1975), “A model of regional growth-rate differences along Kaldorian lines”, Oxford Economic Papers, Vol. 27, No. 2, pp. 201-214.

DUMÉNIL, G; LÉVY, D. (1995) “A Post-Keynesian Long-Term Equilibrium with Equalized Profit Rates? A Rejoinder to Amitava Dutt's Synthesis” Review of Radical Political Economy, Vol. 27(2), pp. 135-141.

DUMÉNIL, G; LEVY, D. (1999). “Profit rates: Gravitation and Trends”. EconomiX, PSE: Paris.

FAGUNDES, L.S. (2017). Dinâmica do Consumo, do Investimento e o Supermultiplicador: Uma Contribuição à Teoria do Crescimento Liderado Pela Demanda. Tese de Doutorado - IE-UFRJ. 216p.

FREITAS, F; SERRANO, F. (2015). "Growth rate and level effects, the stability of the adjustment of capacity to demand and the Sraffian supermultiplier". Review of Political Economy, Vol. 27, N.3, pp.258-281.

GAREGNANI, P. (1992). "Some notes for an analysis of accumulation” In: HALEVI, J; LAIBMAN, D; NELL, E. (orgs). Beyond of the Steady-State: a revival of growth theory. Palgrave Macmillan: Londres.

GAREGNANI, P.. (1980). "Sobre a Teoria do Valor e da Distribuição em Marx e nos Economistas Clássicos” In: GAREGNANI, P. et. Al. (orgs). Progresso Técnico e Teoria Econômica. Hucitec: Campinas.

GODLEY, W; LAVOIE, M. (2007). Monetary Economics: An integrated approach to Credit, Money, Income, Production and Wealth.Palgrave Macmillan: Londres.

GOODWIN, R.M. (1967). A growth cycle, in C.H. Feinstein (ed.), Socialism, Capitalism and Economic Growth, pp. 54-58. Cambridge: Cambridge University Press.

HARROD, R.F. (1939). “An Essay in Dynamic Theory” In: A. Sen (org). Growth Economics. Penguin Books: Middlesex, 1970.

KALDOR, N. (1956). “Alternative Theories of Distribution”. Review of Economic Studies, 23, pp. 83100.

KALECKI, M. (1956). Teoria da Dinâmica Econômica: Ensaio Sobre as Mudanças Cíclicas e a Longo Prazo da Economia Capitalista. Coleção: Os Economistas. 204p.

KEYNES, J.M. (1936). The General Theory of Employment, Interest and Money. Macmillan Press: Cambridge.

LAVOIE, M. (2016). "Convergence towards the normal rate of capacity utilization in Neo-Kaleckian models: The role of non-capacity creating autonomous expenditures". Metroeconomica, 67(1), $172-201$.

LAVOIE, M. (2017). "Prototypes, reality and the growth rate of autonomous consumption expenditures: A rejoinder". Metroeconomica, 68(1), 194-199.

LAVOIE, M. (2018). "Inconsistencies in the note of Dávila-Fernandez, Oreiro and Punzo". Metroeconomica.

MINSKY, H.P. (1986). Stabilizing an Unstable Economy. Yale University Press: New Haven.

NAH, W. J.; LAVOIE, M. (2017). "Long run convergence in a Neo-Kaleckian open economy model with autonomous export growth". Journal of Post Keynesian Economics, Vol. 40, N.2, pp. 223 238.

NIKIFOROS, M. (2013). "The (normal) rate of capacity utilization at the firm level." Metroeconomica 64 (3): 513-38.

NIKIFOROS, M. (2018). "Some comments on the Sraffian supermultiplier approach to growth and distribution". Levy Institute of Economics, Working paper n. 907.

OREIRO, J. L. (2004). “Accumulation Regimes, Endogenous Desired Level Rate of Capacity Utilization and Income Distribution”. Investigación Económica, Vol. 63, N.248.

OREIRO, J. L. (2016). Macroeconomia do Desenvolvimento: uma perspectiva keynesiana. LTC: Rio de Janeiro.

OREIRO, J. L. (2018). Macrodinâmica pós-keynesiana: crescimento e distribuição de renda. Alta Books: Rio de Janeiro. 
OREIRO, J.L; COSTA SANTOS, J.F. (2019). “The Impossible Quartet in a Demand-Led Growth-Supermultiplier model for a small open economy. Working Paper: University of Brasília.

OREIRO, J.L; VALENCIO, A.; CARVALHO, L; SILVA, E. (2018). “Crescimento, Distribuição de Renda e Utilização da Capacidade Produtiva num modelo pós-keynesiano com consistência entre estoques e fluxos. Anais do 46 Encontro Nacional de Economia: Rio de Janeiro. [Disponível em https://www.anpec.org.br/encontro/2018/submissao/files_I/i6-d53c56a51bb65ae7b9f26f43ffbde947.pdf\% $\%$ D

PASINETTI, L. (1961-62). "Rate of Profit and Income Distribution in relation to the Rate of Economic Growth” In: A. Sen (org.). Growth Economics. Penguin Books: Middlesex, 1970.

ROWTHORN, B. (1981). "Demand, Real Wages and Economic Growth". Thames Papers in Political Economy, TP/PPE/81/3.

SANTANA, B; OREIRO, J. L. (2018). "Real Exchange Rate and Structural Change in a Kaldorian Balance of Payments Constrained Growth Model”. Revista de Economia Política, Vol. 38, n.1.

SERRANO, F. (1995). 'Long Period Effective Demand and the Sraffian Supermultiplier.' Contributions to Political Economy 14 67-90.

SKOTT, P. (1989). Conflict and Effective Demand in Economic Growth. Cambridge University Press: Cambridge.

SKOTT, P. (2010). “Growth, Instability and Cycles: Harrodian and Kaleckian models of accumulation and income distribution" In: SETTERFIELD, M. (org.). Handbook of Alternative Theories of Economic Growth. Edward Elgar: Aldershot.

SKOTT, P. (2012). Theoretical and Empirical Shortcomings of the Kaleckian Investment Function. Metroeconomica. 63:1, 109-138.

SKOTT, P. (2016). "Autonomous demand, Harrodian instability and the supply side”. Department of Economics Working Paper Series. 215. Retrieved from http://scholarworks.umass.edu/econ_ workingpaper/215.

SKOTT, P. "Growth, instability and cycles: Harrodian and Kaleckian models of accumulation and income distribution” (2008). Economics Department Working Paper Series. 14.

THIRWALL, A. P. (1979). "The Balance of Payments Constraint as na Explanation of International Growth Rates Differences”. Banca Nazionale del Lavoro Quarterly Review, N.128.

THIRWALL, A.P. (2002). The Nature of Economic Growth. Edward Elgar: Aldershot. 